\title{
On the Minimal Effective Dose of Noradrenaline for Causing the Blood Pressure Elevation in Non-Anesthetized Dogs
}

\author{
By \\ Chikamasa Ninagawa \\ (蛇 川 䚋 正) \\ From the Department of Physiology, Nagasaki University \\ School of Medicine, Nagasaki
}

(Received for publication, September 14, 1953)

No data are available regarding the minimal effective dose of noradrenaline for the blood pressure elevation in animals under physiological conditions. In order to supply such information, the present investigation was undertaken.

In addition, the pressor effects of L-noradrenaline and DL-noradrenaline were compared with that of L-adrenaline in non-anesthetized dogs.

\section{EXPERIMENTAL}

\section{Methods and Results}

\section{(I)}

Minimal effective dose of noradrenaline was determined in 12 healthy normal dogs weighing 5.0 to $13.8 \mathrm{~kg}$.

The femoral artery was laid bare under local anesthesia with $1 \%$ procaine solution and arranged for the blood pressure recording. A small cannula for injection was inserted in the saphenous vein. The blood pressure tracings were taken by means of a mercury manometer. All the experiments were performed without anesthesia.

Synthetic DL-noradrenaline (Sankyo Co.) was dissolved with $1 / 10$ $\mathrm{n} \mathrm{HCl}$ as a $1: 1,000$ dilution and just before the injection further diluted with physiological saline solution. Noradrenaline solution was injected intravenously at a uniform rate of $1 \mathrm{cc}$. per minute for 5 minutes. The amount of noradrenaline injected in the present investigation, was $0.1 \mu \mathrm{g}$., $0.2 \mu \mathrm{g} ., 0.3 \mu \mathrm{g} ., 0.4 \mu \mathrm{g} ., 0.5 \mu \mathrm{g} ., 0.6 \mu \mathrm{g} ., 0.7 \mu \mathrm{g}$. and $1.0 \mu \mathrm{g}$. per kg. of body weight, per minute.

All the data are listed in Table I, and as an example the blood pressure tracings of Exp. 4 are illustrated in Fig. 1.

$0.1 \mu \mathrm{g}$. of noradrenaline per $\mathrm{kg}$. per minute was injected in $3 \mathrm{dogs}$. 
TABLE I

Infusion of Dilute DL-Noradrenaline Solution to the NonAnesthetized Dogs

\begin{tabular}{|c|c|c|c|c|c|}
\hline \multirow{2}{*}{$\begin{array}{l}\text { No. of } \\
\text { Exp. }\end{array}$} & \multirow{2}{*}{$\begin{array}{l}\text { Body weight } \\
\text { and sex }\end{array}$} & \multirow{2}{*}{$\begin{array}{l}\text { Dose of noradrena- } \\
\text { line injected per } \\
\mathrm{kg} . \text { per min. ( } \mu \mathrm{g} .)\end{array}$} & \multicolumn{3}{|c|}{ Blood pressure (mm. Hg.) } \\
\hline & & & $\begin{array}{c}\text { Before } \\
\text { injection }\end{array}$ & $\begin{array}{c}\text { During } \\
\text { injection }\end{array}$ & Elevation \\
\hline 1 & $6.8 \mathrm{~kg}$. 苫 & $\begin{array}{l}0.1 \\
0.2 \\
0.3\end{array}$ & $\begin{array}{l}123 \\
114 \\
113\end{array}$ & $\begin{array}{l}119 \\
117 \\
117\end{array}$ & $\begin{array}{r}-4 \\
3 \\
4\end{array}$ \\
\hline 2 & $6.9 \mathrm{~kg}$. & $\begin{array}{l}0.1 \\
0.2 \\
0.3\end{array}$ & $\begin{array}{l}89 \\
95 \\
88\end{array}$ & $\begin{array}{l}86 \\
94 \\
90\end{array}$ & $\begin{array}{r}-3 \\
-1 \\
2\end{array}$ \\
\hline 3 & $8.2 \mathrm{~kg} . \quad q$ & $\begin{array}{l}0.1 \\
0.2 \\
0.3\end{array}$ & $\begin{array}{l}104 \\
105 \\
109\end{array}$ & $\begin{array}{l}104 \\
109 \\
113\end{array}$ & $\begin{array}{l}0 \\
4 \\
4\end{array}$ \\
\hline 4 & $10.7 \mathrm{~kg}$. & $\begin{array}{l}0.3 \\
0.4 \\
0.5\end{array}$ & $\begin{array}{l}126 \\
117 \\
121\end{array}$ & $\begin{array}{l}132 \\
132 \\
142\end{array}$ & $\begin{array}{r}6 \\
15 \\
21\end{array}$ \\
\hline 5 & $10.2 \mathrm{~kg} . \quad$ ? & $\begin{array}{l}0.4 \\
0.5 \\
1.0\end{array}$ & $\begin{array}{l}145 \\
138 \\
115\end{array}$ & $\begin{array}{l}153 \\
156 \\
148\end{array}$ & $\begin{array}{r}8 \\
18 \\
33\end{array}$ \\
\hline 6 & $5.0 \mathrm{~kg} . \quad$ 우 & $\begin{array}{l}0.4 \\
0.5 \\
0.6\end{array}$ & $\begin{array}{l}165 \\
141 \\
142\end{array}$ & $\begin{array}{l}170 \\
150 \\
153\end{array}$ & $\begin{array}{r}5 \\
9 \\
11\end{array}$ \\
\hline 7 & $7.0 \mathrm{~kg} . \quad \delta$ & $\begin{array}{l}0.4 \\
0.7\end{array}$ & $\begin{array}{l}170 \\
157\end{array}$ & $\begin{array}{l}170 \\
168\end{array}$ & $\begin{array}{r}0 \\
11\end{array}$ \\
\hline 8 & $8.5 \mathrm{~kg} . \quad$ 우 & $\begin{array}{l}0.4 \\
0.5 \\
0.6 \\
0.7 \\
1.0\end{array}$ & $\begin{array}{l}150 \\
116 \\
146 \\
148 \\
152\end{array}$ & $\begin{array}{l}155 \\
132 \\
157 \\
161 \\
169\end{array}$ & $\begin{array}{r}5 \\
16 \\
11 \\
13 \\
17\end{array}$ \\
\hline 9 & $8.6 \mathrm{~kg} . \quad$ ? & $\begin{array}{l}0.3 \\
0.4 \\
0.5 \\
0.6\end{array}$ & $\begin{array}{l}130 \\
145 \\
116 \\
131\end{array}$ & $\begin{array}{l}133 \\
150 \\
129 \\
152\end{array}$ & $\begin{array}{r}3 \\
5 \\
13 \\
21\end{array}$ \\
\hline 10 & $10.1 \mathrm{~kg} . \quad$ 우 & $\begin{array}{l}0.5 \\
0.6 \\
0.7\end{array}$ & $\begin{array}{l}128 \\
143 \\
142\end{array}$ & $\begin{array}{l}132 \\
151 \\
155\end{array}$ & $\begin{array}{r}4 \\
8 \\
13\end{array}$ \\
\hline 11 & $7.7 \mathrm{~kg}$. 우 & $\begin{array}{l}0.4 \\
0.5 \\
0.6\end{array}$ & $\begin{array}{l}137 \\
151 \\
140\end{array}$ & $\begin{array}{l}142 \\
161 \\
162\end{array}$ & $\begin{array}{r}5 \\
10 \\
22\end{array}$ \\
\hline 12 & $13.8 \mathrm{~kg} . \quad$ \& & $\begin{array}{l}0.2 \\
0.3 \\
0.4 \\
0.5 \\
0.6\end{array}$ & $\begin{array}{l}159 \\
164 \\
158 \\
149 \\
156\end{array}$ & $\begin{array}{l}162 \\
171 \\
168 \\
167 \\
172\end{array}$ & $\begin{array}{r}3 \\
7 \\
10 \\
18 \\
16\end{array}$ \\
\hline
\end{tabular}


In two cases the blood pressure descended slightly and in one case no change of the blood pressure was observed.

The injection of $0.2 \mu \mathrm{g}$. noradrenaline per $\mathrm{kg}$. per minute was performed in 4 dogs. A very slight fall of the blood pressure was observed in
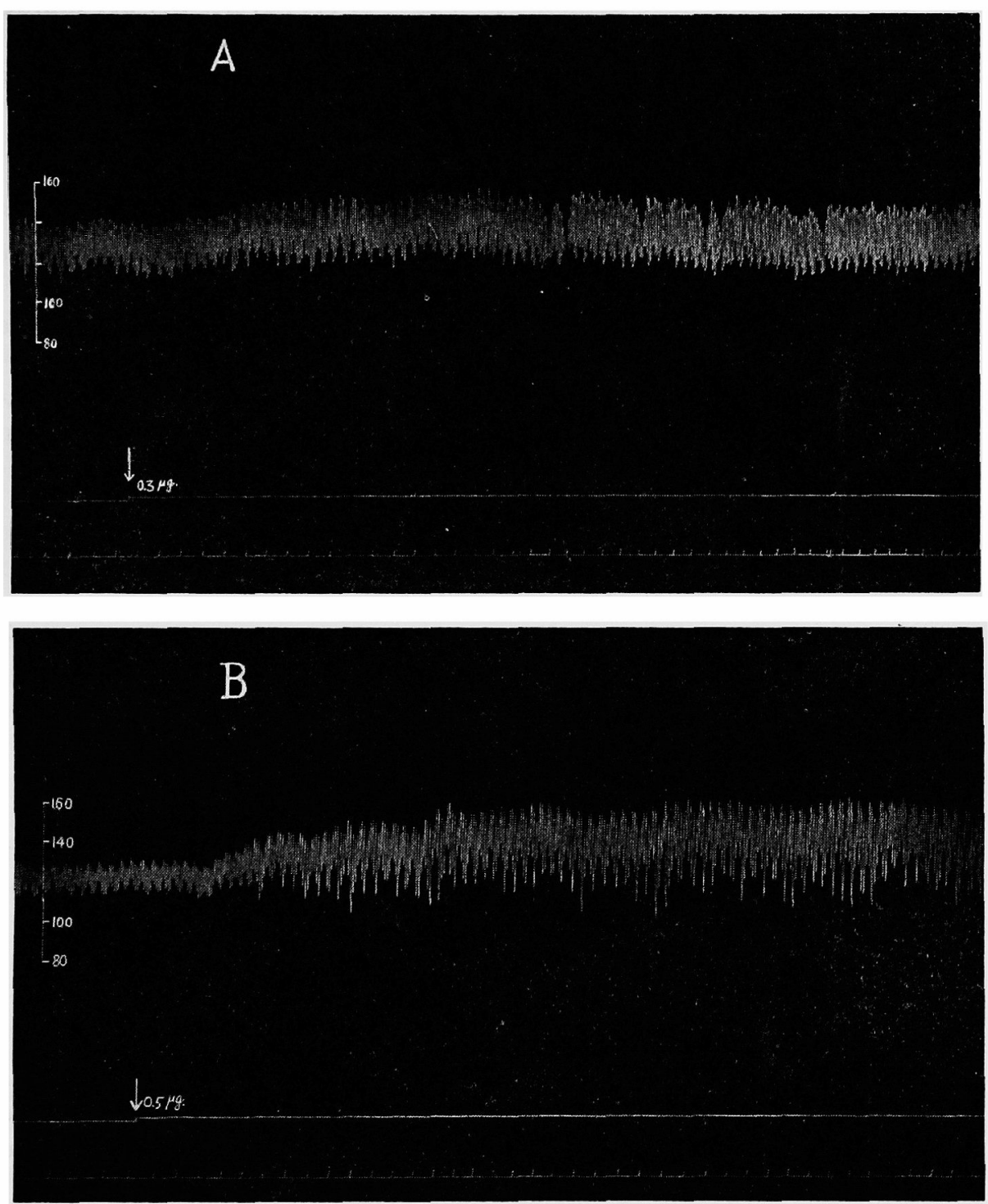

Fig. 1. Records of the blood pressure in Exp. 4. (Reduced to 2/5).

Dog, $10.7 \mathrm{~kg}$. $\mathrm{o}$. Non-anesthetized, non-fastened. A: Injection of DLnoradrenaline in a dose of $0.3 \mu \mathrm{g}$. per $\mathrm{kg}$. per min. $\mathrm{B}$ : The same in a dose of $0.5 \mu \mathrm{g}$. per $\mathrm{kg}$. per min. Time in 6 seconds. 
one dog, while in other 3 dogs it was raised by 3,3 and $4 \mathrm{~mm}$. Hg., respectively.

Noradrenaline in a dose of $0.3 \mu \mathrm{g}$. per kg. per minute was injected in 6 dogs, resulting in elevating the blood pressure by $2-7 \mathrm{~mm} . \mathrm{Hg}$.

The injection of noradrenaline in a dose of $0.4 \mu \mathrm{g}$. per $\mathrm{kg}$. per minute was performed in 8 dogs. In nearly all the cases the pressor effect was observed. The blood pressure was raised by $5-15 \mathrm{~mm}$. Hg. Only in one dog (Exp. 7) the blood pressure remained unaltered.

The injection of $0.5 \mu \mathrm{g}$. noradrenaline per $\mathrm{kg}$. per minute was attempted in 8 dogs. The blood pressure elevated by $4-21 \mathrm{~mm}$. Hg.

$0.6 \mu \mathrm{g}$. (in $6 \mathrm{dogs}$ ), $0.7 \mu \mathrm{g}$. (in $3 \mathrm{dogs}$ ) and $1.0 \mu \mathrm{g}$. (in $2 \mathrm{dogs}$ ) noradrenaline were also tested. In all the cases a more marked rise of the blood pressure was observed.

In order to see the results of all experiments at a glance, the data are summarized in Table II.

The minimal effective dose of DL-noradrenaline for causing the elevation of the blood pressure was thus estimated in the present investigation to be $0.3-0.4 \mu \mathrm{g}$. per $\mathrm{kg}$. of body weight per minute.

\section{TABLE II}

Blood Pressure Response to Each Dose of DL-Noradrenaline in Non-Anesthetized Dogs

\begin{tabular}{c|rrrrrrrr}
\hline $\begin{array}{c}\text { Dose of noradrenaline } \\
\text { ( } \mu \text { g. per kg. per min.) }\end{array}$ & \multicolumn{7}{c}{ Blood pressure elevation (mm. Hg.) } \\
\cline { 2 - 9 } 0.1 & -4, & -3, & 0. & & & & & \\
0.2 & -1, & 3, & 3, & 4. & & & & \\
0.3 & 2, & 3, & 4, & 4, & 6, & 7. & & \\
0.4 & 0, & 5, & 5, & 5, & 5, & 8, & 10, & 15. \\
0.5 & 4, & 9, & 10, & 13, & 16, & 18, & 18, & 21. \\
0.6 & 8, & 11, & 11, & 16, & 21, & 22. & & \\
0.7 & 11, & 13, & 13. & & & & & \\
1.0 & 17, & 33. & & & & & &
\end{tabular}

In 3 healthy normal dogs, weighing $4.6-12.0 \mathrm{~kg}$., the effects of Land DL-noradrenaline were compared to that of L-adrenaline on the blood pressure. The procedure of experiments was almost the same as that above mentioned.

L-noradrenaline-D-bitartrate-monohydrate (Sterling Winthrop), DLnoradrenaline (Sankyo) and L-adrenaline (Sankyo) were used. The amount of L-noradrenaline in $10 \mathrm{mg}$. of L-noradrenaline-D-bitartratemonohydrate was taken as $5 \mathrm{mg}$. One cc. of the solution, containing nor- 
adrenaline or adrenaline in a dose of 2.5-5.0 $\mu$ g. per kg., was injected intravenously in 10 seconds. Marked elevation of the blood pressure was always observed.

In Exp. 13, the effect of $2.5 \mu \mathrm{g}$. L-noradrenaline was almost the same with that of $5.0 \mu \mathrm{g}$. DL-noradrenaline and these were far more stronger than $3.0 \mu \mathrm{g}$. L-adrenaline. $5.0 \mu \mathrm{g}$. DL-noradrenaline was somewhat stronger than $4.0 \mu \mathrm{g}$. I-adrenaline and almost as strong as $5.0 \mu \mathrm{g}$. L-adrenaline. Thus the activity ratios of L-noradrenaline : DL-noradrenaline : L-adrenaline were estimated in this dog to be $2: 1: 1$.

In Exp. 14, the effects of $2.5 \mu \mathrm{g}$. L-noradrenaline and $5.0 \mu \mathrm{g}$. DL-noradrenaline were almost the same. These were weaker than that of $5.0 \mu \mathrm{g}$. L-adrenaline and a little weaker than that of $4.5 \mu \mathrm{g}$. L-adrenaline. $5.0 \mu \mathrm{g}$. DL-noradrenaline was just as strong as $4.0 \mu \mathrm{g}$. L-adrenaline. Activity ratios (L-noradrenaline: DL-noradrenaline: $\mathrm{L}$-adrenaline) were determined in this dog to be $1.6: 0.8: 1$.

Almost the same result was obtained in Exp. 15.

\section{Discussion}

The minimal effective dose of DL-noradrenaline for causing the blood pressure elevation was estimated in this investigation to be $0.3-0.4 \mu \mathrm{g}$. per kg. per minute. As L-noradrenaline was determined to be about twice as much effective as the racemic one, it may not be unfair to take it that the minimal effective dose of L-noradrenaline is $0.15-0.2 \mu \mathrm{g}$. per $\mathrm{kg}$. per minute.

Some reports of the previous investigators (Dragstedt, Wightman and Huffman, ") Wada and Kanowoka ${ }^{2 \prime}$ and Ooisi' ${ }^{3)}$ have indicated that the minimal effective dose of $\mathrm{L}$-adrenaline for raising the blood pressure in nonanesthetized dogs was about $0.2-0.3 \mu \mathrm{g}$. per kg. per minute. Comparing these values it may be concluded that the minimal effective dose of Lnoradrenaline is somewhat smaller than that of L-adrenaline.

The pressor effect of L-noradrenaline in non-anesthetized dogs was found in the present investigation to be 1.6-2.0 times as much as that of L-adrenaline. This agrees well with the results of previous investigators tested in anesthetized dogs.

In dogs with morphine-ether anesthesia, Schultz" estimated the ratio of pressor activity of DL-noradrenaline to DL-adrenaline to be $1.5: 1$. Tainter, Tullar and Luduena ${ }^{5}$ reported that in dogs under phenobarbital anesthesia, L-noradrenaline was $1.64 \pm 0.1$ times as much effective as Ladrenaline. Luduena et al. $\left.{ }^{6}\right)$ estimated in barbitarized dogs that L-noradrenaline was 1.70 times more active than L-adrenaline in elevating the blood pressure.

I have already studied, in conjunction with Drs. T. Suzuki and T. 
Nakamura, ${ }^{7)}$ the activity ratio of L-noradrenaline to L-adrenaline on the blood pressure of non-anesthetized dogs, whose spinal cord was sectioned previously at the level of the lowest cervical segment. L-noradrenaline was found in that time to be 2.1 times more effective than L-adrenaline in the average value.

\section{SUMMARY}

Injecting intravenously DL-noradrenaline at the uniform rate during 5 minutes, the minimal effective dose for causing the blood pressure elevation was determined in non-anesthetized normal dogs. It was estimated to be $0.3-0.4 \mu \mathrm{g}$. per $\mathrm{kg}$. per minute.

In addition, the pressor effects of L-noradrenaline, DL-noradrenaline and L-adrenaline were compared in non-anesthetized normal dogs. Lnoradrenaline was double as much effective as DL-noradrenaline and 1.62.0 times as much active as L-adrenaline.

As the pressor effect of L-noradrenaline is twice as much as that of DL-noradrenaline, the minimal effective does of L-noradrenaline for causing the elevation of the blood pressure in non-anesthetized normal dogs will be $0.15-0.2 \mu \mathrm{g}$. per $\mathrm{kg}$. per minute.

My thanks are due to Prof. T. Suzuki for his helpful advice.

\section{References}

1) Dragstedt, Wightman, \& Huffman, Amer. J. Physiol., 1928, 84, 307.

2) Wada, \& Kanowoka, Tohoku J. Exp. Med., 1935, 27, 9.

3) Ooisi, ibid., 1942, 44, 329.

4) Schultz, Hygienic Lab. Bull., 1909, No. 55, $31 \mathrm{ff}$.

5) Tainter, Tullar, \& Luduena, Science, 1948, 107, 39.

6) Luduena, Ananenko, Siegmund, \& Miller, J. Pharmacol., 1949, 95, 155.

7) Suzuki, Nakamura, \& Ninagawa, Jap. J. Physiol., 1953, 3, 170. 